\title{
Characteristics and Survival of 927 Moroccan Adults with Acute Myeloid Leukemia: Monocentric Experience
}

\author{
Oum kaltoum Ait Boujmia, Mona Lamchahab, Nezha Hda, Asma Quessar
}

Department of Onco-Hematology, Ibn Rochd University Hospital, Casablanca, Morocco.

\begin{abstract}
Acute myeloïd leukemia (AML) is the most frequent form of acute leukemia among adults and the most aggressive type of leukemia, which is associated with the lowest survival rate. Patients with AML are treated with intensive chemotherapy and many factors could influence the survival of these patients, such as age, cytogenetic abnormalities; white blood cell (WBC) counts. The aim of this work was to study the epidemiological and response profiles of AML adults patients in Morocco. Patients and Methods: A prospective, descriptive study conducted in the Hematology and Pediatric Oncology department, 20 August Hospital Casablanca, and concerned adult patients diagnosed with AML through a period of seven years (January 2011 to December 2017). Statistical analysis was performed using SPSS version 20. The overall survival and disease-free survival were evaluated by using the Kaplan-Meier method. Results: A total of 927 patients diagnosed with AML during the 7 year period. $466(50.3 \%)$ were males and $461(49.7 \%)$ were females. The median age of patients was 46years. The most represented age group was between 18 and 60 years old with a percentage of $83.2 \%$. The FAB subtype M2 occurred most frequently (27\%) followed by M1 (24.8\%). The cytogenetic study showed that the majority of patients had a normal karyotype. The $t(8 ; 21)$ was the most detected balanced translocation in our series and the intermediate cytogenetic group was the most represented group (65.4\%). A total of 461 patients $(53.54 \%)$ were treated according to the protocol AML11. The Disease-free survival (DFS) was significantly better for favorable cytogenetic group as compared to other cytogenetic groups (median survival of 41.58 months for the favorable group versus 29.07 months for the adverse group; $p$-value $=0.02$ ). Conclusion: The age of AML patients was younger compared to other populations. The majority of patients had a normal karyotype and the commonest balanced translocation was the $\mathrm{t}(8 ; 21)$. Survival was higher in patients with good prognosis.
\end{abstract}

Keywords: Acute myeloid leukemia- Adults- epidemiology- Survival analysis Prognosis

Asian Pac J Cancer Biol, 6 (1), 5-13

\section{Introduction}

Acute myeloid leukemia (AML) is the most frequent type of acute leukemia among adults and the most aggressive form of leukemia which is associated with the lowest survival rate [1-3]. It is a highly heterogeneous group of hematological disorders that results from the acquisition of chromosomal aberrations and somatic mutations. These abnormalities lead to the accumulation of myeloid precursor cells arrested at early stages of the maturation and differentiation process (myeblasts) [4-5]. In turn, this immature cell accumulation in the bone marrow and blood is responsible for the appearance of insufficiency medullary symptoms such as, anemia,
Submission Date: 10/29/2020Ａcceptance Date: 01/15/2021

\footnotetext{
Corresponding Author:

Dr. Oum kaltoum Ait Boujmia

Department of Onco-Hematology, Ibn Rochd University Hospital, Casablanca, Morocco.

Email: kaltoum.biologie@gmail.com
} age of AML at diagnosis (in the late sixties), varied from 63 to 71 years and males are more likely to develop this cancer than females. These results have been reported in developed countries such USA, UK, Canada and Australia [7-12].

AML is a set of diseases with different morphologic, cytochemic, immunophenotypic, cytogenetic, and molecular genetic features. Two classification systems were used to diagnose and classify AML: The first international classification FAB distinguishes eight subtypes of AML based on the morphology of the blast 
cells [13] and the new classification WHO is based on the immunophenotypic, genetic and cytogenetic characteristics [14]. Cytogenetic abnormalities are described in the most of AML types and implicated in the diagnosis; prognosis and therapeutic response that make karyotype an indispensable examination in evaluating this cancer [15-18]. Immunophenotyping is an essential complement to cytogenetic analysis; it allows to refine the diagnosis of AML or even to modify it [19].

Patients with AML are treated by intensive chemotherapy with high-dose cytarabine, anthracycline or by hypomethylating agents (HMA) [20-22]. Many clinical factors influence the survival of AML patients, such as age, cytogenetic abnormalities, secondary leukemia, complete remission after the first induction and white blood cell (WBC) count [23-24]. For the standard treatment with intensive chemotherapy (anthracycline and cytarabine), complete remission was seen (CR) in 60-80\% of younger adults. These frequencies have been found in developing countries such as North America and Western Europe [25-27]. However, in developing countries such as Morocco, there is little published informations about the epidemiology and survival of AML patients and there are big differences among AML patients between countries due to socioeconomic, genetic and environmental factors [28].

The aim of the present work was to study the epidemiological, cytologic, cytogenetic characteristics and response profiles of acute myeloid leukemia patients in Morocco.

\section{Materials and Methods}

\section{Study type}

This was a prospective, descriptive study conducted at the Hematology and Pediatric Oncology department, 20 August Hospital, University Casablanca, and concerned adultpatients diagnosed with AML through a period of seven years from January 2011 to December 2017. The patients were from different regions of Morocco and classified according to the French American British (FAB) classification. The diagnosis of AML was confirmed by the complete blood count (CBC), bone marrow aspiration, Cytogenetic analysis, immunophenotyping and myeloperoxidase cytochemical analysis (MPO). However; molecular biology analysis was not made in all patients.

\section{Cytogenetics}

Cytogenetic analysis was made according to standard techniques with RHG banding and the International System for Human Cytogenetic Nomenclature [29]. The patients were divided into three groups according to cytogenetic features: according to the classification proposed by the Southwest Oncology Group [30].

- Favorable risk group: Consisted of patients with inversion of chromosome 16 (inv 16), with translocation $\mathrm{t}(8 ; 21)(\mathrm{q} 22 ; \mathrm{q} 22)$ and patients with translocation $\mathrm{t}(15 ; 17)$ (q22; q12-21).

- Unfavorable risk group: Consisted of patients with chromosomal abnormalities involving the 5, 7, 17 and 3 chromosomes, patients with Complex karyotypes (three or more cytogenetic abnormalities) and patients with 11q23 aberrations other than $\mathrm{t}(9 ; 11)$.

- Intermediate Risk group: Patients with normal karyotypes and patients with Chromosomal Abnormalities that do not fall within the other two groups.

\section{AML-MA 2011 protocol}

The chemotherapy treated patients were treated according to the AML-MA 2011 protocol with combined induction chemotherapy using cytarabine (cytosine arabinoside) and daunorubicin. According to this treatment protocol, patients received two inductions of daunorubicin and cytarabine for the first one in addition of etoposide for the second one, followed by three consolidation phases with cytarabine plus daunorubicin for the first and the third phases and asparginase for the second phase. Patients with hyperleukocytosis were treated with hydroxyurea for before induction phase

Inclusion and Exclusion Criteria for Chemotherapy Treatment:

\section{-Inclusion Criteria}

Patients with age less than or equal to 60 years who are diagnosed with AML .

\section{Absence of organ dysfunction}

- Exclusion criteria

Patients with a confirmed diagnosis aged more than 60 years.

Patients with acute promyelocytic leukemia M3.

Patients with myelodysplastic syndrome (MDS), secondary AML

\section{Remission criteria}

After chemotherapy, complete remission (CR) was defined as the absence of circulating blasts, the presence of less than $5 \%$ of the blasts in the bone marrow.

\section{Statistical analysis}

Statistical analysis was performed with the statistical package for Social Sciences SPSS version 20 (SPSS Inc., Chicago, IL, USA). The values $\mathrm{p}<0.05$ are considered to be significant. The analysis of overall survival (OS) and disease-free survival (DFS) of the patients, survival curves were constructed by the Kaplan-Meier method, using the statistical package SPSS version 16 (SPSS Inc., Chicago, IL, USA). The OS was defined as the interval between the date of diagnosis and the date of death or the date of last follow-up. The DFS was defined as the period between the achievement of complete remission (RC) and relapse or date of death from any cause. The curves of OS and DFS were correlated with cytogenetic. Differences in curves were tested using the log-rank test and p-value $<0.05$ being considered statistically significant. 


\section{Results}

A total of 927 patients were diagnosed with AML between January 2011 and December 2017. 466 (50.3\%) were males and $461(49.7 \%)$ were females; with a sex ratio of 1.01. The median age of all patients was 46 years with a minimum age of 18 years and a maximum of 90 years. 771 (83.2\%) patients were aged from 18-60 (young-adults) and only 156 patients $(16.8 \%)$ were aged more than 60 years old (elderly). The white blood cell (WBC) count was less than $50 \mathrm{G} / \mathrm{L}$ at diagnosis in $71.8 \%$ of patients, ranged between $50 \mathrm{G} / \mathrm{L}$ and $100 \mathrm{G} / \mathrm{L}$ in $13.1 \%$ and greater than $100 \mathrm{G} / \mathrm{L}$ in $13.3 \%$ of patients. The characteristics of the patients are summarized in Table 1 . The majority of patients were from the region of Grand Casablanca (41\%), $15.6 \%$ were from Rabat- sale region and $14.5 \%$ were from Tanger-Tetouan region Figure 1.

Regarding the French-American-British (FAB) classification, the M2 subtype was seen in $27 \%$ of all patients, followed by M1 (24.8\%), and M4 (13.4\%) Table1.

$85.1 \%$ of all patients have benefited from karyotype analysis; the Cytogenetic study revealed that $44 \%$ of

Table 1. Characteristics of Acute Myeloid Leukemia (AML) Cases

\begin{tabular}{|c|c|c|}
\hline & & Patients $(\mathrm{N}=927)$ \\
\hline \multicolumn{3}{|l|}{ Sex N (\%) } \\
\hline & Females & $461(49.7)$ \\
\hline & Males & $466(50.3)$ \\
\hline \multirow[t]{15}{*}{$\mathrm{M}: \mathrm{F}$ ratio } & & 1.01 \\
\hline & Age years (Median) & 46 \\
\hline & Range & $18-90$ \\
\hline & $18-30$ & $215(23.2 \%)$ \\
\hline & $31-40$ & $162(17.5 \%)$ \\
\hline & $41-50$ & $186(20.1 \%)$ \\
\hline & $51-60$ & $208(22.4 \%)$ \\
\hline & $61-70$ & $88(9.5 \%)$ \\
\hline & $71-80$ & $55(5.9 \%)$ \\
\hline & $81-90$ & $13(1.4 \%)$ \\
\hline & Median WBC (G/L) Median & 17 \\
\hline & Range & $0.15-844$ \\
\hline & $<50$ & $666(73.6)$ \\
\hline & $50 \_100$ & $119(13.1)$ \\
\hline & $>100$ & $120(13.3)$ \\
\hline \multicolumn{3}{|c|}{ FAB classification N (\%) } \\
\hline & M0 & $32(3.5)$ \\
\hline & M1 & $230(24.8)$ \\
\hline & M2 & $250(27)$ \\
\hline & M3 & $52(5.6)$ \\
\hline & M4 & $124(13.4)$ \\
\hline & M5 & $46(5)$ \\
\hline & M6 & $37(4)$ \\
\hline & M7 & $3(0.3)$ \\
\hline & Not classified & $153(16.5)$ \\
\hline
\end{tabular}

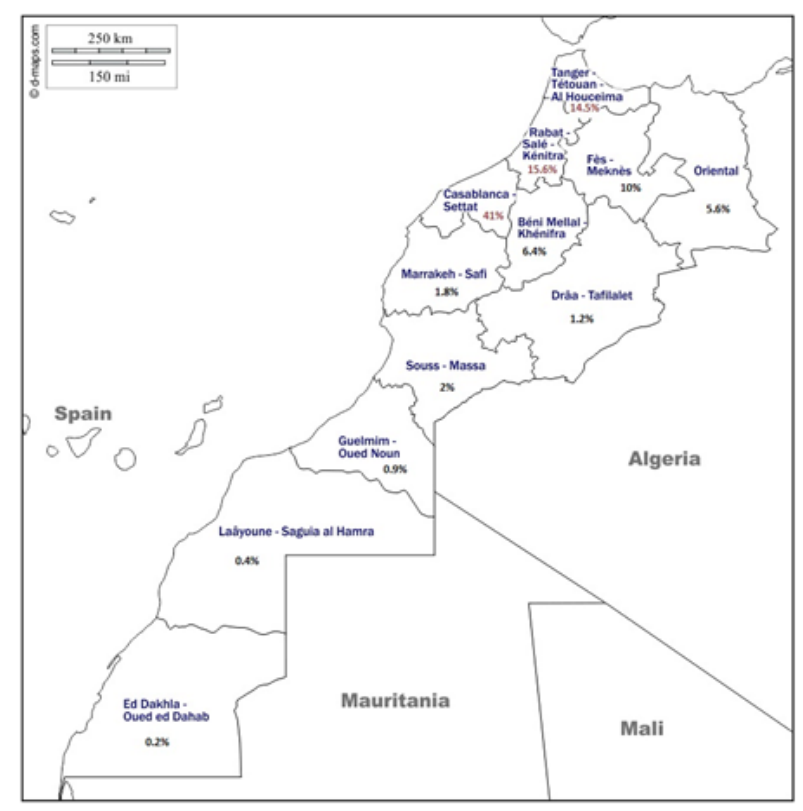

Figure1. Map of Morocco Showing the Geographic Distribution of AML Patients

patients had a normal karyotype, $12 \%$ had acomplex karyotype. For the balanced translocations, the $t(8 ; 21)$ was the most common with a frequency of $8.4 \%$, followed by inv16 $(4.7 \%)$ and $t(15 ; 17)(3.9 \%)$. Trisomy 8 was the most common numerical abnormality in our study (5.3\%) Table 2. Concerning the cytogenetic groups, the intermediate cytogenetic group was the most represented group (65.4\%), followed by unfavorable cytogenetic group $(17.6 \%)$ and favorable cytogenetic group (17\%)Table 2.

For the annual number of AML patients, the highest annual number was recorded in 2012 (172 cases) and after the 2012 outbreak, the number of AML cases declined Figure 2.

Chemotherapy: 461 patients $(53.54 \%)$ were treated with cytarabine (cytosine arabinoside) and daunorubicin.

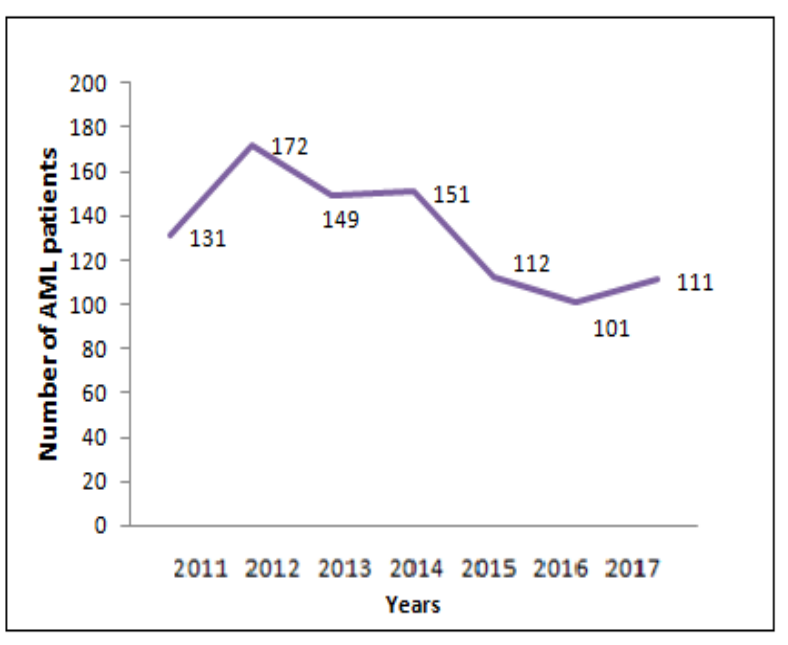

Figure 2. Annual Number of AML Patients 
Table 2. Cytogenetic Characteristics of Acute Myeloid Leukemia (AML) cases

\begin{tabular}{|c|c|c|}
\hline Karyotype & Number of patients & $\%$ \\
\hline $\mathrm{t}(8 ; 21)$ & 66 & 8,4 \\
\hline $\mathrm{t}(15 ; 17)$ & 31 & 3,9 \\
\hline Inv16 & 37 & 4,7 \\
\hline Complex & 95 & 12 \\
\hline Trisomy 8 & 42 & 5,3 \\
\hline Normal & 347 & 44 \\
\hline Trisomy 21 & 10 & 1,3 \\
\hline Trisomy 4 & 4 & 0,5 \\
\hline AnyTrisomy & 26 & 3,3 \\
\hline Monosomy 7 & 21 & 2,7 \\
\hline Monosomy 5 & 7 & 0,9 \\
\hline Monosomy 9 & 3 & 0,4 \\
\hline Any Monosomy & 26 & 3,3 \\
\hline Hyperdiploidy & 15 & 1,9 \\
\hline Monosomy X & 3 & 0,4 \\
\hline Monosomy Y & 7 & 0,9 \\
\hline Del 11 & 19 & 2,4 \\
\hline Inv2 & 1 & 0,1 \\
\hline Inv3 & 1 & 0,1 \\
\hline $\mathrm{t}(3 ; 3)$ & 1 & 0,1 \\
\hline $\mathrm{t}(3,5)$ & 1 & 0,1 \\
\hline Der1 & 1 & 0,1 \\
\hline $\mathrm{t}(11 ; 3)$ & 2 & 0,3 \\
\hline $\mathrm{t}(2,20)$ & 1 & 0,1 \\
\hline $\mathrm{t}(3,18)$ & 1 & 0,1 \\
\hline $\mathrm{t}(3,21)$ & 1 & 0,1 \\
\hline $\mathrm{t}(5,11)$ & 1 & 0,1 \\
\hline $\mathrm{t}(5,16)$ & 1 & 0,1 \\
\hline $\mathrm{t}(6,11)$ & 1 & 0,1 \\
\hline $\mathrm{t}(7,11)$ & 1 & 0,1 \\
\hline $\mathrm{t}(8,16)$ & 1 & 0,1 \\
\hline $\mathrm{t}(9,11)$ & 2 & 0,3 \\
\hline $\mathrm{t}(9,22)$ & 9 & 1,1 \\
\hline der 11 & 1 & 0,1 \\
\hline $\mathrm{t}(10,17)$ & 1 & 0,1 \\
\hline $\mathrm{t}(11,19)$ & 1 & 0,1 \\
\hline $\mathrm{t}(14,15)$ & 1 & 0,1 \\
\hline \multicolumn{3}{|c|}{ Cytogenetic groups } \\
\hline Favorable & 139 & 17 \\
\hline Intermediaite & 134 & 65,4 \\
\hline Unfavorable & 516 & 17,6 \\
\hline Total & 789 & 100 \\
\hline
\end{tabular}

\section{Survival}

The mean overall survival (OS) was 31 months and the mean free survival (LFS) was 20 months. The 5-year EFS and OS Kaplan-Meier estimate were 19.9\% and $41.1 \%$, respectively (Figure 3 ).We compared DFS and

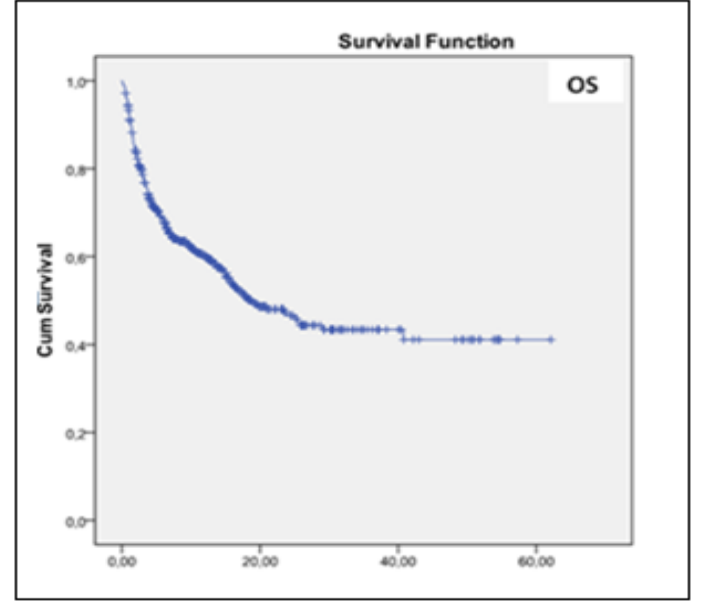

Figure 3. Kaplan-Meier Survival Curves of Overall Survival (OS)

OS between the different cytogenetic groups, the mean DFS differed significantly between different groups (mean survival of 24.5 months for the favorable group versus 14.83 months for the adverse group; $p$-value = 0.02). The favorable group had longer EFS and OS than other groups and the adverse cytogenetic group was associated with shorter EFS and OS, but, OS did not differ significantly between these cytogenetic groups (mean OS survival of 31.22 months in the favorable group versus 24.72 months in the adverse group; $p$-value $=0.40)$ (Figure 4$)$.

\section{Discussion}

The median age of our patients was 46 years and the extreme range in age was from 18 years to 90 years. This age was similar to that reported by Bekadja et al in the Algerian population [31]. In contrast, this age was lower than that reported in many other studies, which prove the youthful character of the Moroccan AML patients [7-12-23-32-34]. On the other hand study by Sultan et al in the Pakistan population, reported a median age of 37.5 [35] Table 3.

The age between 18 and 60 years was the most represented age bracket in our series $(83.2 \%)$. In the study of Padilha et al, patients were predominantly younger than 60 years old (81.6\%). Similarly, in the study by Sultan et al $76 \%$ of all AML patients ( aged between 15-85) were under 50 years old [35-36]. However, according to SEER statistics patients older than age 65 represent approximately 55\% of AML cases [37]. This disagreement between studies might be explained by the sample size, the recruitment of pediatric patients, differences in demographic characteristics across countries (the pace of population aging, increased life expectancy....), environmental and genetic factors which could play a crucial role in the appearance of this cancer at a younger age in our AML patients [38-39]. The distribution of the population according to sex revealed a slight male predominance; a similar result was reported in most 
Table 3. Characteristics of AML Diagnosis in some Populations

\begin{tabular}{|c|c|c|c|c|c|c|c|}
\hline Study & $\begin{array}{l}\text { The current study } \\
\text { (Morocco) }\end{array}$ & $\begin{array}{l}\text { Bekadja et al } \\
\text { (Algeria) [31] }\end{array}$ & $\begin{array}{c}\text { Sultan et al } \\
\text { (Pakistan) [35] }\end{array}$ & $\begin{array}{l}\text { Wahlin et al } \\
\text { (Sweden) [32] }\end{array}$ & $\begin{array}{c}\text { Shyshet al } \\
\text { (Canada) [33] }\end{array}$ & $\begin{array}{l}\text { Smith et al } \\
\text { (UK) [23] }\end{array}$ & $\begin{array}{l}\text { Phekoo et al } \\
\text { (England) [34] }\end{array}$ \\
\hline Number of patients & 927 & 1426 & 125 & 113 & $* * *$ & 717 & 507 \\
\hline Sex ratio & 1.01 & 1.16 & 1.5 & $* * *$ & 1.25 & 1.25 & 1.53 \\
\hline Age years (Median) & $46(18-90)$ & $45(16-82)$ & $37.5(15-85)$ & $63(17-91)$ & $64(20-64)$ & 68.7 & $71(16-98)$ \\
\hline Most represented age class & $18-60(83.2 \%)$ & $* * *$ & $<50$ years $(76 \%)$ & & $* * *$ & $* * *$ & $\leq 55(52.91 \%)$ \\
\hline
\end{tabular}

***, Not available

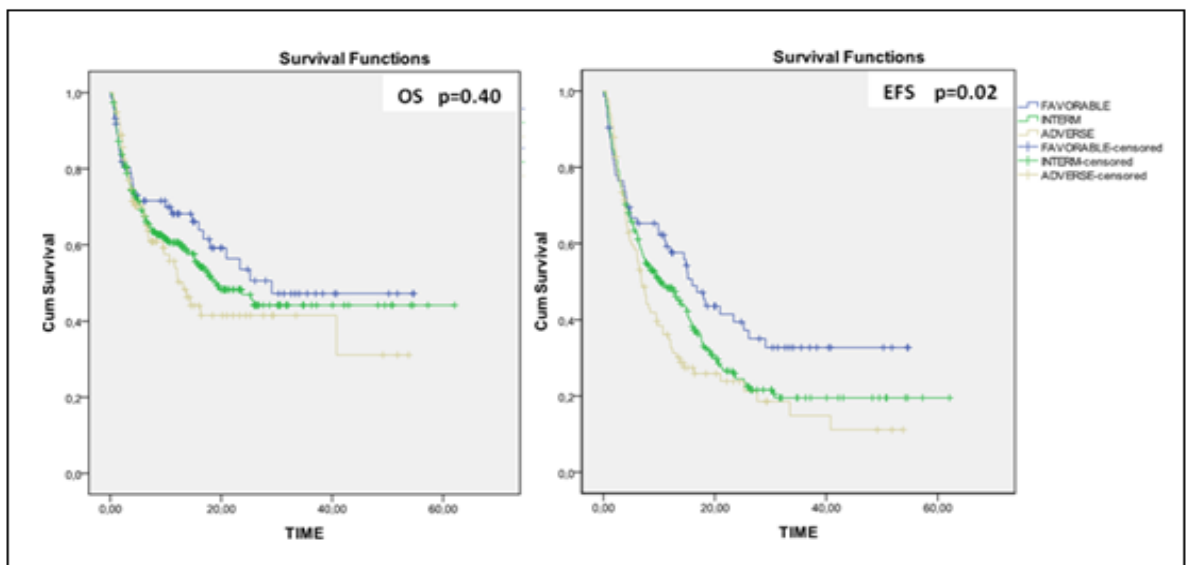

Figure 4. Survival Estimated by Kaplan-Meier Analysis According to Cytogenetic Risk Groups. (A) Overall Survival and (B) Disease-free Survival (DFS)

countries [23-31-33-35-40].

The AML Patients come to the Hematology and Pediatric Oncology department, 20 August Hospital (The closest public hospital to Casablanca) from different regions of Morocco and the majority of them were from the most densely populated region of Morocco, Grand Casablanca with a percentage of $39.4 \%$.

In AML, leukocytosis is a major prognostic factor.In our series, $13.3 \%$ of patients had WBC counts higher than $100.000 / \mathrm{mm}^{3}$. Our results agreed with previous studies by $\mathrm{Xu}$ et al., Viana et al., and Imamura et al. who found that the percentage of patients with WBC counts $>100,000 /$ $\mathrm{mm}^{3}$ is between $12 \%$ and $15 \%$ [41-43].

In this study, M2 was the most common FAB subtype, which confirmed our previous study results [44]. Many other studies also reported that AML-M2 is the most common subtype among both AML adults and pediatric patients [31-45-46]. However, in the studies of Kakepoto et al and Bennett et al, M4 was the most common FAB subtype [47-48] and M5 was found to be the most predominant subtype in the studies of Mertelsmann et al and van der et al [49-50]. These differences could be caused by variations in the genetic background between populations [47].

The karyotype is an essential examination when evaluating AML; chromosomal abnormalities detected on karyotype are one of the most powerful prognostic factors. $44 \%$ of patients had a normal karyotype (NK-AML), this result was in agreement with the reported frequency $(40-50 \%)$ in the literature [51]. The complex karyotype was seen in $12 \%$ of all patients, in the literature, AML patients with complex karyotype account for approximately $10-15 \%$ of adult AML, wich is in agreement with our result $[52-54]$. The $t(8 ; 21)$ was the most common karyotypic abnormalitieswith a frequency of $8.4 \%$, the frequency of this abnormality varied between $5 \%$ and $10 \%$ of all AML cases and its incidence decreases with age: it's the most common among children and young adults not in patients aged more than 60 years old [55-63]. Other authors obtained similar results [58, 59, 64, 65].

The frequency of $t(15 ; 17)$ was $4 \%$, a similar result was reported by Khoubila et al in Moroccan young AML population [65]. In our series, the inv16 represents $4.7 \%$, this frequency was similar to that reported in a Tunisian population by Gmiddne et al [66]. Trisomy 8 was the most common numerical abnormality in our study with a frequency of $5.3 \%$, a similar result was found by khoubila et al and this frequency was lower than that reported in Tunisian cohort (7\%) [65-65].

The frequencies of prognostic groups in our population were $17 \%$ for the favorable group, $65.4 \%$ for the intermediate group and $17.6 \%$ for the adverse group respectively similar results were reported by other authors [48-67, 68]. However, these results were different to the finding of Khoubila et al in Moroccan young AML population (18 to 60 years), who reported that $19.5 \%$ had favorable cytogenetics, $68 \%$ had intermediate and $12.5 \%$ had poor risk, this difference could be explained by the inclusion of patients aged more than 60 years in our study, the decline in the number of the southern Moroccan AML patients, changes in demographic characteristics of our population [65].

In our series, the annual number of AML patients reduced after the 2012 year, due to the construction of 
health facilities such as the built in 2012 of the new public University Hospital (the Mohammed VI) in Marrakech city in which South Moroccan patients receiving their treatment.

The 5-year overall survival (OS) and event-free survival (EFS) rates were $41.1 \%, 19.9 \%$ respectively. Similarly, other authors reported that, the 5-year survival was less than $50 \%$ in adult patients younger than 60 and less than $20 \%$ in older patients $[4,69,70]$.

In a series of 104 Moroccan AML patients treated according to AML 06/96 protocol, the overall survival at 5 years was $9 \%$, these results were insufficient in comparison with the literature [71], compared to this study, there is a big improvement in our results. However, these improvements would be more satisfactory if we can find positive solutions to the major causes of failure seem to be delayed in diagnosis, early (prior to start of therapy) and induction deaths, induction failures and abandonment of therapy.

Cytogenetics play an important role in the treatment and prognosis of AML. In this work, we observed that patients with poor prognosis and intermediate had worse survival from AML and better survival in patients with good prognosis, which showed that Cytogenetics is an important prognostic factor in AML. Similar to results from other studies [34, 72-76].

In conclusion, the age of AML Moroccan patients was younger compared to other populations; M2 was the commonest FAB subtype of AML among our population followed by M1. The majority of our patients had a normal karyotype. Commonest balanced translocation was the $t(8 ; 21)$. Survival was better in patients with good prognosis. Further national multicenter studies are needed to confirm these results.

\section{Conflicts of Interest}

The authors declare no conflicts of interest.

Authors' contributions:

- Ait Boujmia Oum Kaltoum : Collected and analyzed the data, Wrote the paper.

- Lamchahab Mouna: provided clinical information, evaluation and advice.

- Nezha Hada: performed karyotyping.

- Quessar Asma: supervised the work, discussed the study results and implications and commented on the manuscript at all stages, correted the paper.

\section{References}

1. Siegel R, Naishadham D, Jemal A. Cancer statistics, 2012. CA: A Cancer Journal for Clinicians. 2012 01;62(1):10-29. https://doi.org/10.3322/caac.20138

2. Wang H, Naghavi M, Allen C, Barber RM, Bhutta ZA, Carter A, Casey DC, et al. Global, regional, and national life expectancy, all-cause mortality, and cause-specific mortality for 249 causes of death, 1980-2015: a systematic analysis for the Global Burden of Disease Study 2015. The Lancet. 2016 Oct;388(10053):1459-1544. https://doi.org/10.1016/ s0140-6736(16)31012-1

3. Forman D, Stockton D, Møller H, Quinn M, Babb P, De Angelis R, Micheli A. Cancer prevalence in the UK: results from the EUROPREVAL study. Annals of Oncology. 2003 04;14(4):648-654. https://doi.org/10.1093/annonc/mdg169

4. Döhner H, Weisdorf DJ, Bloomfield CD. Acute Myeloid Leukemia. Longo DL. New England Journal of Medicine. 201509 17;373(12):1136-1152. https://doi.org/10.1056/ nejmra1406184

5. Lowenberg B, Downing JR, Burnett A. Acute Myeloid Leukemia. New England Journal of Medicine. 1999 09 30;341(14):1051-1062. https://doi.org/10.1056/ nejm199909303411407

6. Bain B. Leukaemia Diagnosis. 3rd ed. Oxford: Blackwell Publishing. Chapter 2, Acute Leukemia: Immunophenotypic, Cytogenetic and molecular genetic analysis in the classification of Acute Leukemia-the EGIL, MIC, MIC-M and WHO Classifications. $2003 ;$;p.57-143.

7. Shallis RM, Wang R, Davidoff A, Ma X, Zeidan AM. Epidemiology of acute myeloid leukemia: Recent progress and enduring challenges. Blood Reviews. 2019 07;36:70-87. https://doi.org/10.1016/j.blre.2019.04.005

8. Dores GM, Devesa SS, Curtis RE, Linet MS, Morton LM. Acute leukemia incidence and patient survival among children and adults in the United States, 2001-2007. Blood. 2012;119(1):34-43

9. Gangatharan SA, Grove CS, P'ng S, O'Reilly J, Joske D, Leahy MF, Threlfall T, Wright MP. Acute myeloid leukaemia in Western Australia 1991-2005: a retrospective populationbased study of 898 patients regarding epidemiology, cytogenetics, treatment and outcome. Internal Medicine Journal. 2013 08;43(8):903-911. https://doi.org/10.1111/ imj.12169

10. Smith A, Howell D, Patmore R, Jack A, Roman E. Incidence of haematological malignancy by sub-type: a report from the Haematological Malignancy Research Network. British Journal of Cancer. 2011 Nov;105(11):1684-1692. https://doi. org/10.1038/bjc.2011.450

11. Howlader N, Noone A, Krapcho M, Miller D, Brest A, Yu M, et al. SEER Cancer statistics review, 1975-2016. Bethesda, MD: National Cancer Institute; 2019https:// seer. cancer.gov/csr/1975 2016/ [based on November 2018 SEER data submission, posted to the SEER web site, April 2019. Accessed 4/18/2019]..

12. Østgård LSG, Nørgaard M, Nørgaard JM, Severinsen, sengeløv H, Friis LS, Jensen MK, Nielsen OJ. Data quality in the Danish National Acute Leukemia Registry: a hematological data resource. Clinical Epidemiology. 2013 09;:335. https://doi.org/10.2147/clep.s48411

13. Vardiman JW, Thiele J, Arber DA, Brunning RD, Borowitz MJ, Porwit A, Harris NL, et al. The 2008 revision of the World Health Organization (WHO) classification of myeloid neoplasms and acute leukemia: rationale and important changes. Blood. 200907 30;114(5):937-951. https://doi. org/10.1182/blood-2009-03-209262

14. Arber DA, Orazi A, Hasserjian R, Thiele J, Borowitz MJ, Le Beau MM, Bloomfield CD, Cazzola M, Vardiman JW. The 2016 revision to the World Health Organization classification of myeloid neoplasms and acute leukemia. Blood. 201605 19;127(20):2391-2405. https://doi.org/10.1182/ blood-2016-03-643544

15. Marcucci G, Mr??zek K, Bloomfield CD. Molecular heterogeneity and prognostic biomarkers in adults with acute myeloid leukemia and normal cytogenetics. Current Opinion in Hematology. 2005 01;12(1):68-75. https://doi. org/10.1097/01.moh.0000149608.29685.d1

16. Smith ML, Arch R, Smith L, Bainton N, Neat M, Taylor C, Bonnet D, et al. Development of a human acute myeloid leukaemia screening panel and consequent identification of novel gene mutation in FLT3 and CCND3. British Journal 
of Haematology. 2005 02;128(3):318-323. https://doi. org/10.1111/j.1365-2141.2004.05324.x

17. Tamamyan G, Kadia T, Ravandi F, Borthakur G, Cortes J, Jabbour E, Daver N, et al. Frontline treatment of acute myeloid leukemia in adults. Critical Reviews in Oncology/ Hematology. 2017 02;110:20-34. https://doi.org/10.1016/j. critrevonc.2016.12.004

18. Kansal R. Acute myeloid leukemia in the era of precision medicine: recent advances in diagnostic classification and risk stratification. Cancer Biol Med. 2016;13(1):41-54. https://doi.org/10.28092/j.issn.2095-3941.2016.0001

19. Ambayya A. recent advances in diagnosis of acute myeloid leukaemia:A review. Asian J Multidis Stud. 2013;1(5):145-6.

20. Daver N, Cortes J, Kantarjian H, Ravandi F. Acute myeloid leukemia: advancing clinical trials and promising therapeutics. Expert Review of Hematology. 201603 17;9(5):433-445. https://doi.org/10.1586/17474086.2016 .1158096

21. Dombret H, Gardin C. An update of current treatments for adult acute myeloid leukemia. Blood. 201601 07;127(1):5361. https://doi.org/10.1182/blood-2015-08-604520

22. Bohl SR, Bullinger L, Rücker FG. New Targeted Agents in Acute Myeloid Leukemia: New Hope on the Rise. International Journal of Molecular Sciences. 201904 23;20(8):1983. https://doi.org/10.3390/ijms20081983

23. Grimwade D. The changing paradigm of prognostic factors in acute myeloid leukaemia. Best Practice \& Research Clinical Haematology. 2012 Dec;25(4):419-425. https://doi. org/10.1016/j.beha.2012.10.004

24. Sekeres MA. Differences in prognostic factors and outcomes in African Americans and whites with acute myeloid leukemia. Blood. 200406 01;103(11):4036-4042. https:// doi.org/10.1182/blood-2003-09-3118

25. Fernandez HF, Sun Z, Yao X, Litzow MR, Luger SM, Paietta EM, Racevskis J, et al. Anthracycline Dose Intensification in Acute Myeloid Leukemia. New England Journal of Medicine. 200909 24;361(13):1249-1259. https://doi. org/10.1056/nejmoa0904544

26. Flasshove M, Meusers P, Schütte J, Noppeney R, Beelen DW, Sohrab S, Roggenbuck U, et al. Long-term survival after induction therapy with idarubicin and cytosine arabinoside for de novo acute myeloid leukemia. Annals of Hematology. 2000 Oct 13;79(10):533-542. https://doi.org/10.1007/ s002770000193

27. Holowiecki J, Grosicki S, Robak T, Kyrcz-Krzemien S, Giebel S, Hellmann A, Skotnicki A, et al. Addition of cladribine to daunorubicin and cytarabine increases complete remission rate after a single course of induction treatment in acute myeloid leukemia. Multicenter, phase III study. Leukemia. 200403 04;18(5):989-997. https://doi. org/10.1038/sj.leu.2403336

28. Deschler B, Lübbert M. Acute myeloid leukemia: Epidemiology and etiology. Cancer. 2006;107(9):2099-2107. https://doi.org/10.1002/cncr.22233

29. Gonzalez Garcia JR, Meza-Espinoza JP. Use of the International System for Human Cytogenetic Nomenclature (ISCN). Blood. 2006 Dec 01;108(12):3952-3953. https://doi. org/10.1182/blood-2006-06-031351

30. Slovak ML, Kopecky KJ, Cassileth PA, Harrington DH, Theil KS, Mohamed A, Paietta E, et al. Karyotypic analysis predicts outcome of preremission and postremission therapy in adult acute myeloid leukemia: a Southwest Oncology Group/Eastern Cooperative Oncology Group study. Blood. 2000 Dec 15;96(13):4075-4083. https://doi.org/10.1182/ blood.v96.13.4075

31. Bekadja MA, Hamladji RM, Belhani M, Ardjoun FZ, Abad MT, Touhami H, Ait-Ali H, Zouaoui Z, Sidimansour N,
Hamdi S, Grifi F, Mesli N, Saidi M, Mehalhal N, Bachiri A, Bouhass R, Said YM, Midoun N. A population-based study of the epidemiology and clinical features of adults with acute myeloid leukemia in Algeria: report on behalf of the Algerian Acute Leukemia Study Group. Hematology/ Oncology and Stem Cell Therapy. 2011 Oct;4(4):161-166. https://doi.org/10.5144/1658-3876.2011.161

32. Wahlin A, Hörnsten P, Jonsson H. Remission rate and survival in acute myeloid leukemia: Impact of selection and chemotherapy. European Journal of Haematology. 200904 24;46(4):240-247. https://doi.org/10.1111/j.1600-0609.1991. tb00547.x

33. Shysh AC, Nguyen LT, Guo M, Vaska M, Naugler C, RashidKolvear F. The incidence of acute myeloid leukemia in Calgary, Alberta, Canada: a retrospective cohort study. BMC Public Health. 201708 03;18(1). https://doi.org/10.1186/ s12889-017-4644-6

34. Phekoo K, Richards M, Moller H, Schey S. The incidence and outcome of myeloid malignancies in 2,112 adult patients in southeast England. Haematologica. 2006;91(10):1400-4.

35. Sultan S, Zaheer HA, Irfan SM, Ashar S. Demographic and Clinical Characteristics of Adult Acute Myeloid Leukemia - Tertiary Care Experience. Asian Pacific Journal of Cancer Prevention. 201602 05;17(1):357-360. https://doi. org/10.7314/apjcp.2016.17.1.357

36. Padilha SL, Souza EJDS, Matos MCC, Domino NR. Acute myeloid leukemia: survival analysis of patients at a university hospital of Paraná. Revista Brasileira de Hematologia e Hemoterapia. 2015 01;37(1):21-27. https:// doi.org/10.1016/j.bjhh.2014.11.008

37. Appelbaum FR, Gundacker H, Head DR, Slovak ML, Willman CL, Godwin JE, Anderson JE, Petersdorf SH. Age and acute myeloid leukemia. Blood. 200605 01;107(9):34813485. https://doi.org/10.1182/blood-2005-09-3724

38. Mizutani S. Recent advances in the study of the Hereditary and environmental basis of childhood leukemia. tnt. J. Hematol. 1998;68:131-43. https://doi.org/10.1016/s09255710(98)00036-x

39. Kwiatkowski A. Dietary and other environmental risk factors in acute leukaemias. European Journal of Cancer Prevention. 1993 03;2(2):139-146. https://doi.org/10.1097/00008469199303000-00006

40. Parkin DM W, Ferlay J, Raymond L, Young J, editors. Cancer Incidence in Five Continents. Lyon, France: IARC Scientific Publications. 1997; VII. IARC Scientific Pub(143).

41. Xu X, Tang Y, Song H, Yang S, Shi S, Wei J. Longterm outcome of childhood acute myeloid leukemia in a developing country: experience from a children's hospital in China. Leukemia \& Lymphoma. 2010 Oct 07;51(12):22622269. https://doi.org/10.3109/10428194.2010.518653

42. Viana MB, Cunha KCCMS, Ramos G, Murao M. Leucemia mielóide aguda na criança: experiência de 15 anos em uma única instituição. Jornal de Pediatria. 2003 Nov;79(6). https://doi.org/10.1590/s0021-75572003000600006

43. Imamura $T$, Iwamoto $S$, Kanai R, Shimada A, Terui K, Osugi Y, Kobayashi R, Tawa A, Kosaka Y, Kato K, Hori H, Horibe K, Oda M, Adachi S. Outcome in 146 patients with paediatric acute myeloid leukaemia treated according to the AML99 protocol in the period 2003-06 from the Japan Association of Childhood Leukaemia Study. British Journal of Haematology. 201208 28;159(2):204-210. https://doi. org/10.1111/bjh.12030

44. AitBoujmia O, Nadifi S, Dehbi H, Kassogue Y, Lamchahab M, Quessar A. Association of Glutathione S-transferase Genes (M1 and T1) with the Risk of Acute Myeloid Leukemia in a Moroccan Population. Middle East Journal of Cancer. 2017 January;8(1):7-12. 
45. Muhammad Arif Sadiq, Ghassan Umair Shamshad, Nadir Ali, Eijaz Ghani, Suhaib Ahmed, Ma.ham Arshad. HAEMATOLOGICAL MANIFESTATIONS AND FREQUENCY OF FAB SUBTYPES IN PATIENTS OF ACUTE MYELOID LEUKAEMIA: A SINGLE CENTER STUDY. Pakistan Armed Forces Medical Journal. 2015;65(5):610-5.

46. Asif M, Iqbal Z, Iqbal F. Acute leukaemia in adults: Morphological profile of 101 patients. Ann King Edward Med Uni. 2000;6-4:343-8.

47. Kakepoto G, Burney I, Zaki S, Adil S, Khurshid M. Longterm outcomes of acute myeloid leukemia in adults in Pakistan. J Pak Med Assoc. 2002;52:482-6.

48. Bennett J, Begg C. Eastern Cooperative Oncology Group study of the cytochemistry of adult acute myeloid leukemia by correlation of subtypes with response and survival. Cancer Res. 1981;41:4833-9.

49. Mertelsmann R, Tzvi Thaler H, To L, Gee T, McKenzie S, Schauer P, Friedman A, Arlin Z, Cirrincione C, Clarkson B. Morphological classification, response to therapy, and survival in 263 adult patients with acute nonlymphoblastic leukemia. Blood. 1980 Nov 01;56(5):773-781. https://doi. org/10.1182/blood.v56.5.773.773

50. van der Reijden H, van Rhenen D, Lansdorp P, van't Veer M, Langenhuijsen M, Engelfriet C, von dem Borne A. A comparison of surface marker analysis and FAB classification in acute myeloid leukemia. Blood. 198303 01;61(3):443-448. https://doi.org/10.1182/blood.v61.3.443. bloodjournal613443

51. Butt F, Lodhi Y. A Review of 170 cases of acute leukemias. Ann King Edward Med Uni. 1999;5(1):1-3.

52. Mrózek K, Marcucci G, Paschka P, Whitman SP, Bloomfield CD. Clinical relevance of mutations and gene-expression changes in adult acute myeloid leukemia with normal cytogenetics: are we ready for a prognostically prioritized molecular classification?. Blood. 200609 07;109(2):431448. https://doi.org/10.1182/blood-2006-06-001149

53. Bowen D, Groves MJ, Burnett AK, Patel Y, Allen C, Green C, Gale RE, Hills R, Linch DC. TP53 gene mutation is frequent in patients with acute myeloid leukemia and complex karyotype, and is associated with very poor prognosis. Leukemia. 200807 03;23(1):203-206. https:// doi.org/10.1038/leu.2008.173

54. Perrot A, Luquet I, Pigneux A, Mugneret F, Delaunay J, Harousseau J, Barin C, Cahn J, Guardiola P, Himberlin C, Recher C, Vey N, Lioure B, Ojeda-Uribe M, Fegueux N, Berthou C, Randriamalala E, Béné MC, Ifrah N, Witz F. Dismal prognostic value of monosomal karyotype in elderly patients with acute myeloid leukemia: a GOELAMS study of 186 patients with unfavorable cytogenetic abnormalities. Blood. 201107 21;118(3):679-685. https://doi.org/10.1182/ blood-2010-09-307264

55. Grimwade D, Hills RK, Moorman AV, Walker H, Chatters S, Goldstone AH, Wheatley K, Harrison CJ, Burnett AK. Refinement of cytogenetic classification in acute myeloid leukemia: determination of prognostic significance of rare recurring chromosomal abnormalities among 5876 younger adult patients treated in the United Kingdom Medical Research Council trials. Blood. 201007 22;116(3):354-365. https://doi.org/10.1182/blood-2009-11-254441

56. Arber DA, Stein AS, Carter NH, Ikle D, Forman SJ, Slovak ML. Prognostic Impact of Acute Myeloid Leukemia Classification. American Journal of Clinical Pathology. 2003 05;119(5):672-680. https://doi.org/10.1309/ em7kcqr4glmhrcx 4

57. Valk PJ, Verhaak RG, Beijen MA, Erpelinck CA, van Doorn-Khosrovani SBVW, Boer JM, Beverloo HB,
Moorhouse MJ, van der Spek PJ, Löwenberg B, Delwel R. Prognostically Useful Gene-Expression Profiles in Acute Myeloid Leukemia. New England Journal of Medicine. 200404 15;350(16):1617-1628. https://doi.org/10.1056/ nejmoa040465

58. Cheng Y, Wang Y, Wang H, Chen Z, Lou J, Xu H, Wang H, Qian W, Meng H, Lin M, Jin J. Cytogenetic profile of de novo acute myeloid leukemia: a study based on 1432 patients in a single institution of China. Leukemia. 200905 28;23(10):1801-1806. https://doi.org/10.1038/leu.2009.107

59. Sanderson RN, Johnson PRE, Moorman AV, Roman E, Willett E, Taylor PR, Proctor SJ, Bown N, Ogston S, Bowen DT. Population-based demographic study of karyotypes in 1709 patients with adult Acute Myeloid Leukemia. Leukemia. 200601 19;20(3):444-450. https:// doi.org/10.1038/sj.leu.2404055

60. Klaus M, Haferlach T, Schnittger S, Kern W, Hiddemann $\mathrm{W}$, Schoch C. Cytogenetic profile in de novo acute myeloid leukemia with FAB subtypes M0, M1, and M2: a study based on 652 cases analyzed with morphology, cytogenetics, and fluorescence in situ hybridization. Cancer Genetics and Cytogenetics. 2004 Nov;155(1):47-56. https://doi. org/10.1016/j.cancergencyto.2004.03.008

61. Bacher U, Kern W, Schnittger S, Hiddemann W, Haferlach T, Schoch C. Population-based age-specific incidences of cytogenetic subgroups of acute myeloid leukemia. Haematologica. 2005 Nov;90(11):1502-10.

62. Bruserud Ø, Hovland R, Wergeland L, Huang T, Gjertsen B. Flt3-mediated signaling in human acute myelogenous leukemia (AML) blasts: a functional characterization of Flt3-ligand effects in AML cell populations with and without genetic Flt3 abnormalities. Haematologica. 2003 Apr;88(4):416-28.

63. Mrózek K, Marcucci G, Paschka P, Bloomfield CD. Advances in molecular genetics and treatment of corebinding factor acute myeloid leukemia. Current Opinion in Oncology. 2008 Nov;20(6):711-718. https://doi.org/10.1097/ cco.0b013e32831369df

64. Mitterbauer M, Kusec R, Schwarzinger I, Haas O, Lechner $\mathrm{K}$, Jaeger U. Comparison of karyotype analysis and RT-PCR for AML1/ETO in 204 unselected patients with AML. Ann Hematol. 1998;76:139-43.

65. N Khoubila, M Bendari, NHda, M Lamchahab, MQachouh, M Rachid, A Quessar. Cytogenetic profile of a representative cohort of young adults with de novo acute myéloblasticleukaemia in Morocco. 2019 October;238:1-9.

66. Gmidène A, Sennana H, Wahchi I, Youssef YB, Jeddi R, Elloumi M, Saad A. Cytogenetic profile of a large cohort of Tunisian de novo acute myeloid leukemia. Hematology. 2012 01;17(1):9-14. https://doi.org/10.1179/10245331 2x13221316477417

67. Patel JP, Gönen M, Figueroa ME, Fernandez H, Sun Z, Racevskis J, Van Vlierberghe P, Dolgalev I, Thomas S, Aminova O, Huberman K, Cheng J, Viale A, Socci ND, Heguy A, Cherry A, Vance G, Higgins RR, Ketterling RP, Gallagher RE, Litzow M, van den Brink MR, Lazarus HM, Rowe JM, Luger S, Ferrando A, Paietta E, Tallman MS, Melnick A, Abdel-Wahab O, Levine RL. Prognostic Relevance of Integrated Genetic Profiling in Acute Myeloid Leukemia. New England Journal of Medicine. 201203 22;366(12):1079-1089. https://doi.org/10.1056/ nejmoa1112304

68. Hong W, Medeiros BC. Unfavorable-risk cytogenetics in acute myeloid leukemia. Expert Review of Hematology. 2011 04;4(2):173-184. https://doi.org/10.1586/ehm.11.10

69. Döhner H, Estey EH, Amadori S, Appelbaum FR, Büchner T, Burnett AK, Dombret H, Fenaux P, Grimwade D, Larson 
RA, Lo-Coco F, Naoe T, Niederwieser D, Ossenkoppele GJ, Sanz MA, Sierra J, Tallman MS, Löwenberg B, Bloomfield CD. Diagnosis and management of acute myeloid leukemia in adults: recommendations from an international expert panel, on behalf of the European LeukemiaNet. Blood. $20100121 ; 115(3): 453-474$. https://doi.org/10.1182/ blood-2009-07-235358

70. Stein EM, Tallman MS. Emerging therapeutic drugs for AML. Blood. 201601 07;127(1):71-78. https://doi. org/10.1182/blood-2015-07-604538

71. Qachouh M, Quessar A, Harif M, Benchekroun S. Acute myeloblastic leukemia in adults: evaluation of the AML 06/96 protocol. Tunis Med. 2003;81(7):461-5.

72. Rockova V, Abbas S, Wouters BJ, Erpelinck CAJ, Beverloo HB, Delwel R, van Putten WLJ, Löwenberg B, Valk PJM. Risk stratification of intermediate-risk acute myeloid leukemia: integrative analysis of a multitude of gene mutation and gene expression markers. Blood. 201107 28;118(4):1069-1076. https://doi.org/10.1182/ blood-2011-02-334748

73. Virgo KS, Burkhardt EA, Cokkinides VE, Ward EM. Impact of Health Care Reform Legislation on Uninsured and Medicaid-Insured Cancer Patients. The Cancer Journal. 2010 Nov;16(6):577-583. https://doi.org/10.1097/ ppo.0b013e31820189cb

74. Juliusson G, Antunovic P, Derolf A, Lehmann S, Möllgård L, Stockelberg D, Tidefelt U, Wahlin A, Höglund M. Age and acute myeloid leukemia: real world data on decision to treat and outcomes from the Swedish Acute Leukemia Registry. Blood. 200904 30;113(18):4179-4187. https:// doi.org/10.1182/blood-2008-07-172007

75. Gupta M, Mahapatra M, Saxena R. Cytogenetics' impact on the prognosis of acute myeloid leukemia. J Lab Physicians. 2019 Apr-Jun;11(2):133-137. doi: 10.4103/JLP.JLP_164_18. PMID: 31160852; PMCID: PMC6543945.

76. Löwenberg B, Ossenkoppele GJ, van Putten W, Schouten HC, Graux C, Ferrant A, Sonneveld P, Maertens J, JongenLavrencic M, von Lilienfeld-Toal M, Biemond BJ, Vellenga E, Kooy MVM, Verdonck LF, Beck J, Döhner H, Gratwohl A, Pabst T, Verhoef G. High-Dose Daunorubicin in Older Patients with Acute Myeloid Leukemia. New England Journal of Medicine. 200909 24;361(13):1235-1248. https:// doi.org/10.1056/nejmoa0901409

\section{(ब) $(9$}

This work is licensed under a Creative Commons AttributionNon Commercial 4.0 International License. 